\title{
Kønnet subjektivering
}

Dorte Marie SøndergaArd INTRODUCERER BRONWYN DAVIES

endnu temmelig sparsomt, hvad der findes af empirisk forskning, som baserer sig på poststrukturalistisk teori. Der findes dog noget, og internationalt er blandt andre Patti Lather, Elizabeth St.Pierre, Laurel Richardson, Valerie Walkerdine og altså Bronwyn Davies, hvis arbejde artiklen her omhandler, personer, som alle har ydet væsentlige bidrag til poststrukturalistisk baserede empiriske analyser af køn. Poststrukturalistisk tænkning stiller store krav til forskeren, og ikke mindst til den empiriske forsker: Man må kunne arbejde i det uforudsigelige og kunne tåle at bevæge sig i et felt, hvor begreber og forståelsesmodeller hele tiden er i bevægelse. Metodisk findes der ingen faste opskrifter på hverken dataindsamling eller dataanalyse. Forskeren må tilegne sig de metateoretiske perspektiver og selv arbejde med at omsætte dem i kreative analytiske tilgange.

Set i lyset af dette, bliver een af styrkerne i Bronwyn Davies' arbejder, at hun formår 
at åbne den poststrukturalistiske filosofi på en måde, som gør teorien tilgxngelig for andre i en empirisk analytisk forskningssammenhæng. Hun samler og udvikler de teoretiske pointer, som gør det muligt empirisk at analysere og forstå de komplekse processer, hvorigennem subjektivitet, køn, magt, institutioner etc. skabes, opretholdes og ændres. Det væsentligste fokus i hendes samlede produktion ligger på kønnede subjektiveringsprocesser studeret i forskellige former for børne- og uddannelsesinstitutioner, fra børnehavebørn til voksne under uddannelse (Davies 1982, 1989c, 1993, 1996a). Men de senere arbejder inkluderer også ganske andre empiriske felter, og for at nævne nogle af de mere eksotiske gælder det f.eks. hendes studier af kropsliggjorte subjektiveringsprocesser $\mathrm{i}$ henholdsvis japanske og australske kontekster, undersøgt blandt digtere, miljøaktivister og universitetsstuderende (Davies 1999b).

Davies er ganske eksperimenterende i sine metodiske tilgange. Hun bevæger sig fleksibelt mellem interview, observationer, feltnotater og kollektive biografier, der er udarbejdet i workshops med grupper af informanter, som skriver på grundlag af individuelle erindringer (delvist inspireret af Frigga Haugs Errinnerungsarbeit (Haug 1987)). Hun læser eventyr op for børn og lytter til deres forståelser og tolkninger. Hun eksperimenterer med at lære børn at dekonstruere diskurser og storylines, og observerer og videooptager processerne. Hun bruger digte og romaner. Hun bruger egne erindringer. Hun udleverer kameraer og lader informanterne tage billeder og fortælle på grundlag af billederne. Alt sammen for at få adgang til detaljerne i de subtile interaktionsformer, som skaber og reproducerer diskurs og subjektivitet.

\section{SubJEKTET}

Et af de begreber, der står helt centralt i Bronwyn Davies' arbejder, er begrebet om subjektet og om de subjektiveringsproces- ser, subjektet skabes igennem. Davies anvender begrebet subjekt i stedet for identitet, fordi hun ønsker at distancere sig fra den liberalt humanistiske opfattelse af selvet som noget individet iboende, noget den enkelte selv kan tage bevidst ansvar for at udvikle og udfolde. Med subjektiveringsbegrebet ønsker hun at skifte fokus fra det autonome og modsætningsfri selv og i stedet gribe selvet som en processuel, foranderlig, modsætningsfuld og fragmenteret størrelse.

Ethvert barn, ethvert individ, må tilegne sig de måder at se sig selv og verden på, som er tilgxngelige i de diskursive kontekster, barnet/individet indgår i. Barnet/individet må lære sig at læse og fortolke de sociale og kulturelle landskaber, de er en del af, og dermed også at dele de indforståetheder, som diskurserne er opbygget omkring. Og Davies skriver:

"This is not simply a cognitive process of language learning, but also an ability to read and interpret the landscape of the social world, and to embody, to live, to experience, to know, to desire as one's own, to take pleasure in the world as it is made knowable through the available practices and in particular the discursive practices, the patterns of power and powerlesness and one's positioning within them. Correct membership of the social order entails being able to read situations correctly such that what is obvious for everyone else is also obvious to you. It involves knowing how to be positioned and to position yourself as a member of the group who knows and takes for granted what other people know and take for granted in a number of different settings." (Davies 1999, "The Process of Subjectification"l).

I hendes forståelse er subjektiviteten delvist et resultat af sådanne subjektiveringsprocesser, som de er foregået igennem det enkelte menneskes særlige livshistorie og til stadighed foregår gennem denne histories og de aktuelle subjektiveringsbetingelsers gensidi- 


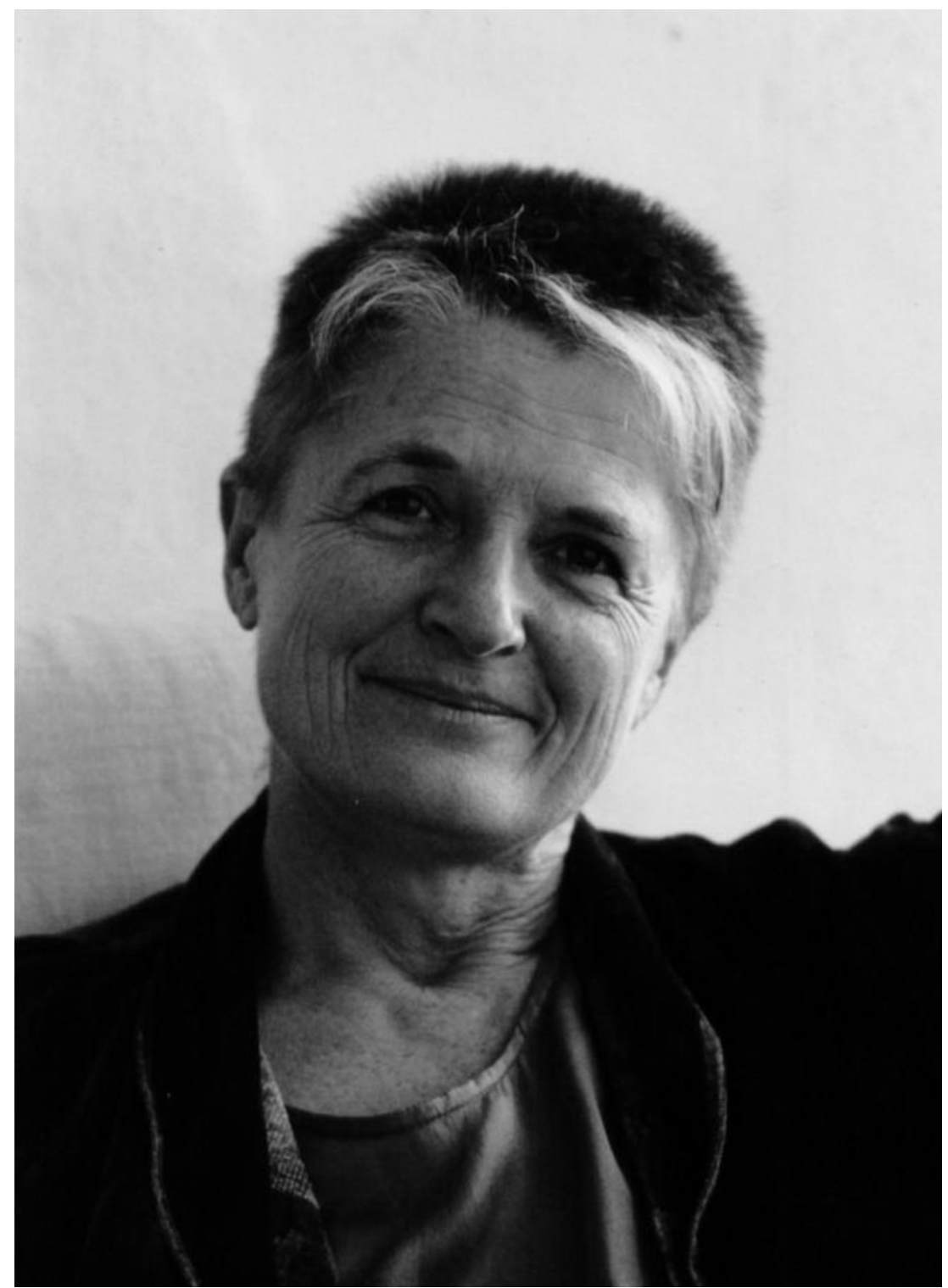

Foto: Anne-Mette Kruse 
ge diffundering (Davies 1994). Vendingen "to desire as ones own" eller "to take up as ones own” er central for Davies' forståelse af subjektivitetens tilblivelse og opretholdelse: Individet gør de diskursive muligheder til sine egne. Mulighederne bliver til det "desire"/de ønsker og de tanker, følelser og erfaringer, individet oplever som noget dybt personligt og helt unikt. Det diskursive er, for Davies, ikke bare ydre kontekst, men selve det, det subjektive er gjort af.

De subjektpositioner, det enkelte individ har erfaret som sine og gjort til sine, făr derfor også en anderledes betydning i den enkeltes subjektivering, end subjektpositioner, der tilbydes for første gang og opdages som helt nye muligheder. I den forbindelse er det vigtigt at understrege forståelsen af erfaring, som kropslig, sanselig, praktiseret, følt oplevelse - noget der kan være italesat, men som langt fra behøver at være det. Livshistoriske erfaringer bliver på denne måde tematiseret i Davies' udgave af en poststrukturalistisk forståelse af individers subjektiveringsprocesser. Men forståelsen lægger samtidig vægt på at fremhæve de måder, livshistorien udfoldes og fortælles på, som skæringspunkter mellem synkront og diakront formede diskurser, storylines ${ }^{2}$ og magtrelationer.

I dette perspektiv kan individet siges allerede at være subjekt, før det fødes, fordi begrebet om barnet som afgrænset individualitet allerede før fødslen er etableret, og begrebet dermed venter barnet. Med Althusser formulerer Davies det på den måde, at barnet allerede før fødslen hyldes som subjekt; subjektiveringen er så at sige begyndt før barnet overhovedet ser dagens lys, og barnet glider umærkeligt videre ind $\mathrm{i}$ de diskursive indforståetheder, som gradvist sætter det i stand til at svare denne hyldest som subjekt, endog et særligt subjekt, på en adækvat måde.

Det, at Davies lægger så stor vægt på subjektet, at hun tematiserer livshistoriens betydning og samtidig lægger vægt på at forstå subjektiveringsprocessernes også ik- ke-italesatte karakter, har fået nogle til at læse hende som psykoanalytisk poststrukturalist. Davies tager imidlertid selv afstand fra den psykoanalytiske traditions essentialiserende tendenser, ikke mindst i relation til køn. Det spændende ved hendes arbejde bliver på den baggrund, at hun, gennem sin egen poststrukturalistisk baserede forskningsanalytiske praksis, bryder psykoanalysens monopol på adgangen til at studere komplekse menneskelige fænomener som f.eks. livshistorie, kropsliggjort subjektivering og ikke-italesatte interaktionsdynamikker mellem subjekter og mellem subjekter og kollektive diskurser.

\section{SKOLEDISKURSER OG SUBJEKTIVERING}

Disse er nogle af de teoretiske perspektiver, der ligger til grund for de meget detaljerede og på mange måder overraskende indfølte og sanselige empiriske analyser, der løber som bærende erkendelsesmæssige elementer igennem Bronwyn Davies' tekster. Selv bryder Davies sig hverken om ordene empati eller indføling - i stedet anvender hun begrebet "embodied" om sin måde at skrive og analysere på. Hvad den bedste danske oversættelse af "embodied" vil være, er jeg ikke sikker på, men ser man på den analytiske praksis, der karakteriseres som "embodied", så indeholder den noget i retningen af det, der i gamle dage inden for marxistisk psykologi hed, perspektivoverføring, men i en udgave, der fokuserer den kropslige, sanselige, emotionelle og kognitive oplevelse som et integreret hele: Davies kombinerer sine teoretiske indsigter med en bestræbelse på at sætte sig i de subjekters position, som indgår i det empiriske materiale, hun analyserer, hvad enten disse subjekter er 4-årige piger med magtambitioner på børnehavens legeplads, japanske digtere, velmenende skoleledere eller "adfærdsvanskelige" drenge, som kravler rundt på tagene og råber op om at hade alle mennesker og brænde skoler ned.

Stærkt forenklet kan pointen i den analy- 
tiske praksis beskrives som rettet mod: 1. at udlæse de diskurser, som empiriens subjekter mødes med; 2. at udlæse de diskurser, som subjekterne selv benytter og forstår sig og omgivelserne igennem; 3 . at se hvor eventuelle modsætninger og brydninger diskurserne imellem opstår og fungerer, og 4. at analysere hvilke betingelser, som disse brydninger igen giver for de subjektiveringsprocesser, som empiriens personer løbende er hvirvlet ind $i$.

Hvad er det for eksempel for common sense diskurser og brudstykker af pædagogisk psykologiske diskurser, som den føromtalte dreng på skoletaget, Robert on the Roof, bliver forstået igennem af de andre børn, af lærerne og til en vis grad også af ham selv midt i hans kaotiske oprør? Robert og de andre "adfærdsvanskelige" børn kender godt dele af de diskurser, de bliver forstået igennem, men af forskellige årsager har de ikke adgang til at anvende dem som deres egne ("to take them up as their own"). Disse diskurser støder sammen med de diskurser, som børnene i øvrigt er subjektiveret igennem - som de gennem deres livshistorie og deres tilværelse uden for skolen har gjort til deres egne. Når disse børn derfor "gør" deres subjektivering i skolekonteksten, genkendes de ikke af autoriteter og medelever som nogle, der "gør skolebarn" på en korrekt måde. De bliver i stedet (gen)kendt og derpå positioneret som afvigere, specificeret inden for forskellige afvigerkategorier. Og når først den proces er aktiv, har selv fragmenter af korrekt skolebarnsadfærd vanskeligt ved at trænge igennem autoriteternes aflæsning af børnene. I den forstand er enertien i de diskursive kategoriseringer, der sker af både børn og voksne, ganske voldsom, og både børn og voksne har vanskeligt ved at bryde den diskursive magt, der fastholder dem i deres positioner.

Davies' arbejde med lærere og skoleledere viser, hvor vanskeligt det også kan være for de professionelle og autoriteterne at bryde ud af de diskurser, som de er subjek- tiveret igennem. De professionelle, autoriteterne, bliver blinde for de positioneringsprocesser, de selv er aktive deltagere i. De bliver blinde over for den magt, de er en del af. Både lærere og elever, marginaliserede elever og elever positioneret som normale, er så meget en del af de diskursive praksiser, som hverdagslivet består af, at de alle bidrager aktivt til disse praksissers reproduktion uden blik for vejene ud af deres magtdynamikker.

Det er i forhold til denne fastlåsthed, at man skal finde nogle af Davies' ambitioner, når det gxlder uddannelsesforskningen: for hende bliver den poststrukturalistiske analyse en mulighed for at åbne nogle af de diskursive selvfølgeligheder, der fastholder subjekterne i deres magt-afmagtspositioner inden for de forskellige uddannelseskontekster: "...the takeup of poststructuralist discourse enables a radical disruption of the taken-for-granted readings of educational practices, so opening up moments in which the participants can go beyond the conditions of their subjection" (Davies 1999. "Poststructuralist theory in practice: working with 'behaviourally disturbed' children"). I praktiseringen af en poststrukturalistisk pædagogik bliver det netop denne åbning af subjektiveringsprocesserne og deres konkrete subjektiveringseffekter på børn og voksne, som kommer til at stå centralt. De modstridende diskurser synliggøres, og Davies viser (i førnævnte artikel sammen med Cath Laws), hvordan man kan nå marginaliserede børn gennem at (aner/gen)kende deres særlige diskurser og forsøgsvis skabe bro mellem dem og skolediskursen noget der blandt andet kan gøres ved at lære børnene at se diskurserne som sideordnede, og at håndtere dem som muligheder man kan bevæge sig ind og ud af.

\section{MAGTEN OG}

\section{DET FEMINISTISKE PROJEKT}

Bronwyn Davies har i sine analyser dette engagerede blik for de magt- og afmagt- 
spositioner, som diskurserne gør tilgængelige for individerne, der subjektiveres igennem dem. Hun er optaget af relationen mellem voksne og børn, mænd og kvinder, hvide og sorte, lærere og elever, kompetente og inkompetente, "gode børn/unge" og "marginaliserede børn/unge". Det er andetgørelsesprocesserne, som de sidstnævnte $i$ alle disse relationspar løbende er involveret $i$, der specielt interesserer Davies, og hun søger i sine analyser at nå bag de konsekvenser, andetgørelsesprocesserne har, for at se, hvordan subjektiveringen foregår, hvordan den opretholdes, produceres og eventuelt brydes.

Magten forstås i den sammenhæng ikke som en ting eller en essens, der kan beskrives, men som et komplekst sæt af relationer mellem mennesker og relationer mellem mennesker og videnssystemer / mønstre af diskurser. Magt bliver på den måde ikke bare en undertrykkende kraft eller et resultat af "nogens" begrænsende bestræbelser. Magt udgør også en "positiv", skabende kraft (Davies 1999. "A body of writing: a summary").

Davies følger Butler i sin beskrivelse af magtens ambivalens: subjektiveringen indebærer en underkastelse under diskursive praksisser, men der er samtidig tale om en underkastelse, som overhovedet muliggør det subjekt, der kan fungere som aktivt handlende og endog overskride subjektiveringens begrænsninger (Butler 1997). Underkastelse og mestring er to samtidige processer, de er to sider af samme sag, nemlig af subjektets konstituering. Man bliver $\mathrm{i}$ en vis forstand magtfuld af at mestre de eksisterende diskurser. Men inden for de eksisterende diskurser sker der løbende fordelinger af relative magtpositioner, og de til enhver tid andetgjorte subjekter, de markerede subjekter, som Davies foretrakker at kalde dem, vil dermed have interesse $i$ at gennemskue deres egen subjektiveringsproces og i muligheden for at åbne de positioner, som eksisterende diskurser henviser dem til.
Det er i den sammenhæng, begrebet om handling (agency) skal forstås, og det er her afsæettet til en poststrukturalistisk feminisme ligger. I den humanistiske tænknings subjektbegreb lå/ligger udgangspunktet for handling $\mathrm{i}$ det autonome individ $\mathrm{i}$ form af en afgrænset, kontekstfri kapacitet til at vide og forfølge sin vilje. I modsætning til dette begreb tænkes den poststrukturalistiske handlekapacitet ind i subjektets diskursivt konstituterende betingelser. Og det første spørgsmål, som det her bliver relevant at stille, lyder: hvilke bevægelsesmuligheder produceres overhovedet inden for de eksisterende diskursive konfigurationer og dermed den eksisterende diskursive magt? Det næste spørgsmål: hvor ligger mulighederne for at omforme magtens mønstre, de mønstre som konstituerer os - og hvor ligger mulighederne for at rekonstituere den eksisterende tilstands legalitet (Butler 1995; Davies 1999).

Davies' feministiske projekt formuleres som på een gang en overskridelse og en omslutning af to andre feminismer, nemlig den liberale feminisme og den radikale feminisme. Den liberale feminismes ambition om at give kvinder adgang til mænds privilegier (ligestille kvinder på mænds præmisser), og den radikale feminismes bestræbelser på at synliggøre og få anerkendt det kvindelige på linie med det mandlige (ligeværdsstrategien), bliver til delstrategier inden for den feminisme, som udvikles med poststrukturalismens muligheder for radikalt at bryde kønsdualismens henvisning af individer til de to afgrænsede kønskategorier.

I artiklen "The Problem of Desire" (1990, gentrykt i 1999) beskriver Davies sine feministiske ambitioner på denne måde:

"As a feminist, I desire a world in which anyone's sex/gender is made relevant only in the process of biological reproduction. I desire a world in which there are multiple ways of being available to everyone, that multiplicity not being organised around the 
male/female dualism. I long for a world in which each of us can move legitimately and recognizably from any one of those multiple ways of being to another. I long for the 'female' ways of being that are available to me now to be valued and available to anyone".

Denne tilstand, hvor kønnets grænsesætninger begrænses til et absolut minimum, drejer sig ikke om f.eks. at fejre det androgyne, bisexualiteten eller andre blandingsfænomener; det er ikke tilstrækkeligt. Det er heller ikke tilstrækkeligt at frakoble begreberne mandlig og kvindelig fra de øvrige binære oppositioner, der er knyttet til kønsdualismen (hoved - krop, rationalitet emotionalitet, orden - kaos, individuel social etc.). Det egentlige brud ligger, ifølge Davies, i frakoblingen af begreberne mandlig og kvindelig fra subjektet, og altså fra subjektiveringsprocesserne. Davies hylder med andre ord ikke ideen om, at kønnet bevæges fra en bipolær til en bimodal tilstand, eftersom den bimodale tilstand altid vil indbære muligheden for at konstruktionen glider tilbage i hierarkiske dualismer.

Både den liberale og den radikale feminisme bør indgå som delstrategier/delperspektiver, når det gælder ambitionen om at ryste kønskonstruktionen. Men det potentiale, poststrukturalismen tilbyder, består i at se disse tiltag som netop delstrategier $\mathrm{i}$ forhold til den overordnede ambition om radikalt at overskride de diskurser, som suger alle subjekter uanset køn ind i kønreproducerende praksisser. I en konkret politisk virkelighed består Davies' strategier i en taktisk identifikation af de diskurser, der indgår i det politiske felt, og en manøvrering, der bygger på en samtidig anvendelse af samme (magtfulde) diskurser kombineret med en strategisk placeret underminering af dem, eventuelt gennem introduktion af nye konstruktioner og storylines.

I den poststrukturalistiske feministiske forskningskontekst tildeler Davies imidlertid selve skriveprocessen en særlig status, blandt andet inspireret af Cixious. "We do not know what we can speak/write into existence until we've done it, since even those imaginary worlds through which we conjure up a possibility different from this world are discursively produced. We need to write and speak utopias, we need to rewrite the past and the present, we need to write and speak all of our selves, not just our minds but our bodies, to imagine who we might be if we were not constituted within the bonds of the male/female dualism" (Davies 1999. "The Problems of Desire").

"Subjektets død", som jo har bekymret mange feminister $\mathrm{i}$ forbindelse med den poststrukturalistiske tænkning - for hvorfra kunne feministisk handling tage sit udgangspunkt, hvis ikke fra et (humanistisk?) selv, bliver i denne sammenhæng forstået som en forudsætning for et radikalt brud med kønsdualismen og altså for en egentligt overskridende feminisme. Davies' pointe her er, at påstanden om subjektets død kun giver mening i forhold til det maskulinistisk humanistiske subjektbegreb, hvor individ og kollektiv forstås som adskilte og antagonistiske størrelser. Det er det autonome, det iboende, det dekontekstualiserede og ahistoriske subjekt, som poststrukturalismen opløser og som den poststrukturalistiske feminisme ser som sin radikalt overskridende mulighed. Det diskursivt konstituerede selv derimod findes; det kan leves, nydes, analyseres, reflekteres etc. qua sin konstituerede status. Og det er herfra det kvindeligt subjektiverede individ har mulighed for at genskrive sig og at bryde med gamle diskurser og gamle strukturer.

\section{Noter}

1. Henvisningen til Davies, 1999a gælder en bog, der samler hendes væsentligste teoretiske artikler fra perioden 1990-1999. Bogen udkommer på Alta Mira Press (Sage Publications), men henvisningen gxlder foreløbig manuskriptet, hvis sideangivelser ikke vil følge den endeligt trykte bog. Derfor henvises til bogen og kapitlet, men ikke siden. 
2. Storylines udgør en særlig struktur i diskurserne. Der er med storylinebegrebet (sådan som jeg udlæser det af Davies' analytiske praksis) tale om kondensatet af en naturaliseret og selvfølgelig kulturel fortælling, der oftest også anvendes som tolkningsramme for egne og andres handlinger og handlingssekvenser. Der er tale om et fortællingsforløb, hvori særlige subjektpositioner eksponeres og stilles til rådighed som identifikationsmuligheder for aftagende subjekter (Søndergaard 1999). En storyline kan f.eks. dreje sig om, hvordan romantisk kærlighed gøres, med anvisning af subjektpositioner for unge mænd og kvinder, forældre, rivaler etc.

\section{REFERENCER}

- Butler, Judith (1995): Contingent Foundations. In Feminist Contentions. A Philosophical Exchange. Introduction: Linda Nicholson. Routledge, New York 1995.

- Butler, Judith (1997): The Psychich Life of Power. Stanford University Press, Stanford.

- Davies, Bronwyn (1982): Life in the classroom and playground. The accounts of primary school children. Routledge and Kegan Paul, London.

- Davies, Bronwyn (1983): The role pupils play in the social construction of classroom order. British Journal of Sociology of Education, no4.

- Davies, Bronwyn (1989a): The discursive production of the male/female dualism in school settings. Oxford Review of Education, nol 5.

- Davies, Bronwyn (1989b): Education for sexism. A theoretical analysis of the sex/gender bias in education. Educational Philosophy and Theory, no21.

- Davies, Bronwyn (1989c): Frogs and Snails and Feminist Tales: Preschool children and gender. Allen and Unwin, Sydney.

- Davies, Bronwyn (1990a): Lived and imaginary narratives and their place in taking oneself up as a gendered being. Australian Psychologist, no 25. - Davies, Bronwyn (1990b): The Problems of Desire. Social Problems, no37.

- Davies, Bronwyn (1991): The concept of agency: a feminist poststructuralist analysis. Social Analysis, no30.
- Davies, Bronwyn (1992): Women's subjectivity and feminist stories. In C. Ellis and M. Flaherty (eds.): Investigating subjectivity: Research on lived experience. Sage Publications, Newbury CA.

- Davies, Bronwyn (1993): Shards of Glass. Children reading and writing beyond gendered identities. Allen and Unwin, Sydney.

- Davies, Bronwyn (1994): Poststructuralist theory and classroom practice. Deakin University Press, Victoria.

- Davies, Bronwyn (1996a): Power/knowledge/desire. Changing school organisation and management practices. Department of Education, Employment and Youth Affairs, Canberra.

- Davies, Bronwyn (1996b): What makes Australian education strange: Australian education in the Asian context. Australia in its Asian Context, Occasional Paper Series 1/1996. Academy of the Social Sciences in Australia, Canberra.

- Davies, Bronwyn (1998): Psychology's subject. A commentary on the relativism/realism debate. In Parker, I (ed.). Social Constructionism, Discourse and Realism. Sage Publications, London.

- Davies, Bronwyn (1999a in print): A Body of Writing 1990-1999. Alta Mira Press, New York. - Davies, Bronwyn (1999b in print): (In)scribing Body/landscape Relations. Alta Mira Press, New York.

- Davies, Bronwyn and Rom Harré (1990): Positioning: The discursive production of selves. Journal for the Theory of Social Behaviour, 20 (1).

- Davies, Bronwyn and Rom Harré (1991/1992):

Contradiction in lived and told narratives. Research on Language and Social Interaction, no25.

. Haug, Frigga (1987): Female sexualisation.

Verso, London.

- Søndergaard, Dorte Marie (1999 in print): Destabilising Discourse Analysis. Approaches to Poststructuralist Empirical Research. Skriftserie: Køn i den Akademiske Organisation, no7 (distribueres fra Institut for Statskundskab, Københavns Universitet).

Dorte Marie Søndergaard, dr.phil, Roskilde Universitet 